dr hab. Jerzy MICHNIK, prof. UE Wydział Informatyki i Komunikacji, Uniwersytet Ekonomiczny w Katowicach e-mail: jerzy.michnik@ue.katowice.pl

\title{
ZASTOSOWANIE METODY WINGS DO WSPIERANIA DECYZJI W PRZYPADKU WYSTĘPOWANIA ZALEŻNOŚCI MIĘDZY KWESTIAMI NEGOCJACYJNYMI ${ }^{1}$
}

\begin{abstract}
Streszczenie
W negocjacjach częste są sytuacje, w których przestrzeń negocjacyjna i wzorce ofert nie są jasno określone. Jeśli dodatkowo między kwestiami negocjacyjnymi moga pojawić się zależności, wtedy tradycyjne metody, oparte na sumie ważonej ocen cząstkowych, nie są właściwe dla konstrukcji systemu ocen ofert. Jest to miejsce, w którym swoją użyteczność mogą wykazać podejścia o słabszych założeniach. W artykule zaproponowano zastosowanie metody WINGS (Weighted Influence Non-linear Gauge System) celem wsparcia podejmowania decyzji w procesie negocjacji. Metoda WINGS przedstawia ogólne podejście systemowe pomagające rozwiązywać złożone problemy, w których występują powiązane ze sobą czynniki. W szczególności metoda ta może być użyta do oceny wariantów decyzyjnych w sytuacjach, kiedy zależności między kryteriami nie mogą być pominięte. W ramach wstępnego etapu tej metody zespół negocjacyjny konstruuje, reprezentującą problem negocjacyjny, wspólną sieć konceptów (wierzchołków) i ich relacji (łuków). Taka struktura przypomina mapę poznawczą lub przyczynowa. Podstawę sieci stanowią wierzchołki, które odzwierciedlają potencjalne warianty (oferty). U wierzchołka sieci leżą kwestie negocjacyjne (czyli cele, względnie odpowiadające im kryteria). We wnętrzu sieci występują wierzchołki pośrednie, tworzące ścieżki przyczynowe prowadzące od ofert do kwestii. Etap wstępny ma za zadanie pomóc zespołowi negocjacyjnemu w określeniu struktury problemu, a także wspiera proces uczenia się i zrozumienia jego istoty. Drugi, główny etap obejmuje fazę ilościową metody WINGS, pozwalająca zbudować ranking kompromisowych ofert. Użyteczność metody zilustrowano dwoma przykładami przygotowania negocjacj: zakupu partii towaru oraz wyboru systemu informatycznego typu ERP.
\end{abstract}

Słowa kluczowe: negocjacje, podejście systemowe, strukturyzacja problemu, WINGS, wspomaganie negocjacji

\section{APPLICATION OF WINGS METHOD TO SUPPORT DECISION MAKING WITH INTER-DEPENDENCE OF CRITERIA IN NEGOTIATIONS}

\section{Summary}

A situation when negotiation space and templates are not clearly defined is very likely in negotiations. If it also happens that criteria cannot be regarded as independent, then no approach based on weighted additive scoring is suitable for building the offer scoring system. This is an area where other approaches with less limiting assumptions can prove useful. This paper proposes to apply the WINGS (Weighted Influence Non-linear

\footnotetext{
1 Artykuł powstał w ramach projektu sfinansowanego ze środków Narodowego Centrum Nauki przyznanych na podstawie decyzji numer DEC-2013/09/B/HS4/01102.
} 
Gauge System) method, a general systemic procedure for supporting decision making in negotiations. The WINGS method helps solve complex problems involving interrelated factors. In particular, it can be used to evaluate alternatives when the interrelations between criteria cannot be neglected. In the introductory stage, the negotiating team builds a common network of concepts (nodes) and their relations (arrows) representing the negotiation problem. This structure resembles a cognitive or causal map. The bottom nodes represent potential alternatives (offers), while the top nodes represent objectives (issues). The intermediary nodes create causal paths leading from the alternatives to the objectives. This stage helps the negotiation team to structure the problem; it also supports learning and comprehension. The main stage involves quantitative evaluations with the WINGS method that make it possible to build a ranking of compromise solutions. The usefulness of the procedure is illustrated with two examples of preparation for negotiations: the purchase of a batch of goods and the choice of an ERP system.

Key words: group negotiations, problem structuring, supporting negotiations, systemic approach, WINGS

JEL: C44, C65

\section{Wstęp}

W praktyce negocjacyjnej, oprócz typowych, powtarzalnych negocjacji związanych z działalnością operacyjną firmy, występują sytuacje, w których przestrzeń negocjacyjna i wzorce ofert nie sa jasno określone. Ma to miejsce, kiedy przedmiotem negocjacji są na przykład unikalne kontrakty o dużej wartości i poważnych, długoterminowych konsekwencjach. Inny przykład to negocjacje dotyczące problemów społecznych, które dotycza grup o konfliktowych interesach. W takich sytuacjach dużego znaczenia nabiera kwestia przygotowania do negocjacji. W fazie przygotowania, nazywanej też faza prenegocjacyjna, negocjator (pojedyncza osoba lub grupa osób) ma za zadanie wstępnie określić swoje priorytety (kwestie i ich względną wagę) oraz dla każdej kwestii (zakres opcji, jakie może zaakceptować), [Wachowicz, 2013]. Z natury rzeczy (negocjator uwzględnia wiele kwestii negocjacyjnych) do oceny potencjalnych ofert stosuje się różnorodne podejścia wywodzące się $\mathrm{z}$ wielokryterialnych metod wspomagania decyzji [Brzostowski i in. 2012a; Salo, Hämäläinen, 2010]. Waga fazy prenegocjacyjnej znajduje odzwierciedlenie w bogactwie literatury na ten temat. Na przykład można wymienić prace wykorzystujące: popularną metodę SAW [Kersten, i Noronha, 1999], metodę AHP [Brzostowski i in. 2012b; Mustajoki, Hämäläinen, 1999] i rozmytą metodę TOPSIS [Roszkowska, Wachowicz, 2015]. Stosowane są również modele hybrydowe (łączące kilka metod), jak na przykład MARS [Górecka i in. 2014, Górecka i in. 2016]. Zagadnieniom wspomagania decyzji w procesie negocjacji poświęcona została, wydana niedawno, monografia [Roszkowska, Wachowicz, 2016].

Wspólną cechą najczęściej stosowanych metod wielokryterialnych jest klasyczne założenie o niezależności kryteriów. W wielu jednak przypadkach tradycyjne metody, oparte na sumie ważonej ocen cząstkowych, mogą prowadzić do zniekształceń w szacowaniu wzorców i ocenie ofert. Jest to miejsce, w którym swoją użyteczność mogą wykazać podejścia o słabszych założeniach. Należą do nich m.in.: ANP (Analytical Network Process) [Saaty, 2005] i WINGS (Weighted Influence Non-linear Gange System), [Michnik, 2013].

Przedmiotem artykułu jest procedura wspomagania problemów negocjacyjnych, która ma swoje źródła w myśleniu systemowym. Oparta jest ona na metodzie WINGS 
[Michnik, 2013]. Na wstępnym etapie zespół negocjacyjny buduje wspólny model problemu negocjacyjnego. Ma on postać sieci konceptów i powiązań między nimi. Struktura ta przypomina mape poznawczą (cognitive map) lub mape przyczynowa (causal map)2 ${ }^{2}$. Podstawę mapy stanowia potencjalne warianty decyzyjne (oferty), a jej wierzchołek kwestie negocjacyjne, czyli cele (lub powiązane z nimi kryteria). Od wariantów do celów prowadzą ścieżki przechodzące przez koncepty pośrednie reprezentujące powiązania przyczynowo-skutkowe, wiążące warianty z celami. Etap wstępny pomaga zespołowi negocjacyjnemu ustrukturyzować problem, a także ułatwia proces uczenia się i lepszego zrozumienia problemu. W przypadkach złożonych negocjacji etap wstępny można wzbogacić o bardziej rozbudowane procedury strukturyzacji problemu, takie jak SODA czy SSM [Pidd, 2004].

Drugi, główny etap wykorzystuje ilościowe oszacowania, prowadzone w ramach WINGS. Wdrożenie ocen ilościowych pozwala na zbudowanie rankingu rozwiązań kompromisowych. Metoda WINGS reprezentuje ogólne systemowe podejście, którego zadaniem jest pomoc w rozwiązywaniu złożonych problemów obejmujących powiązane ze sobą czynniki o różnym charakterze. W szczególności WINGS może być użyte do wielokryterialnej oceny wariantów decyzyjnych w sytuacji, kiedy nie można pominąć powiązań między kryteriami.

\section{Opis metody WINGS}

Metoda WINGS służy do ilościowej oceny elementów powiązanych w system, który jest modelem sytuacji wymagającej analizy i podjęcia decyzji. W metodzie tej ocenie podlegają dwie charakterystyki dotyczące roli danego składnika w systemie: siła (znaczenie) danego składnika w systemie oraz siła, z jaką oddziałuje on na inne składniki systemu. Cechy te znajdują odzwierciedlenie w akronimie metody. Weighted wskazuje, że wartości określające siłę elementów systemu są wagami, które modyfikują siłę wpływu (influence) poszczególnych elementów na siebie. Przekształcenia matematyczne wprowadzają nieliniowe zależności (non-linear), a gange system odnosi się do ilościowej oceny oddziaływań pomiędzy składnikami systemu. W metodzie WINGS agreguje się wszystkie pośrednie oddziaływania danego składnika na inny składnik, jakie są możliwe w danym systemie. W wyniku uzyskuje się końcową (pełną) wartość siły (znaczenia) tego składnika. Poniżej przedstawiono szczegóły procedury WINGS.

$\mathrm{Na}$ początku użytkownik określa składniki, które według niego są ważne w analizowanym problemie oraz zależności przyczynowo-skutkowe, które występują między nimi. Prowadzenie analizy ułatwia zilustrowanie zależności w postaci sieci powiązań między składnikami. Z formalnego punktu widzenia sieć ta jest grafem skierowanym, w którym wierzchołki reprezentują składniki systemu, a łuki odpowiednie zależności.

Następnie użytkownik dobiera skalę werbalną do oceny obu charakterystyk: znaczenia i siły oddziaływania poszczególnych składników systemu. Liczba punktów skali

\footnotetext{
${ }^{2}$ W odróżnieniu od map poznawczych, w których występują dodatnie i ujemne powiązania, w omawianej sieci istnieje tylko jeden rodzaj zależności: dodatni. Jest to podyktowane względami technicznymi, wynikającymi z charakteru przekształceń matematycznych, a te pojawiają się na następnym etapie.
} 
zależy od intuicji użytkownika. Minimalna, sugerowana liczba powinna obejmować 3 do 5 punktów określających poziom znaczenia i siły oddziaływania, np.: bardzo niski, niski, średni, wysoki, bardzo wysoki. Jeżeli użytkownik ma odczucie, że potrzebuje dokładniejszego rozróżnienia, może dowolnie poszerzyć skalę, np. przez dodanie punktów pośrednich. Biorąc pod uwagę to, że skala przedstawia subiektywne oceny użytkownika, nie wydaje się sensowne, aby zawierała ona znacznie więcej niż 10 punktów, chociaż formalnie metoda nie stawia tu żadnych ograniczeń.

Ze względu na to, że WINGS jest metodą ilościowa, punkty skali werbalnej muszą uzyskać wartości liczbowe. Tu również metoda nie stawia ograniczeń użytkownikowi, jakkolwiek można się zgodzić, że użycie liczb całkowitych może być łatwiejsze i wygodniejsze. Ponadto, zachowanie równowagi pomiędzy znaczeniem a siłą oddziaływania sugeruje użycie tego samego zakresu liczbowego dla obu skali. Liczba jeden wyraża najniższą niezerową wartość. Jest ona punktem odniesienia do oszacowania wyższych poziomów, które określane sa poprzez ich stosunek do poziomu jednostkowego (oznacza to zastosowanie skali ilorazowej). W tym miejscu użytkownik musi wykorzystać swoją wiedzę o problemie oraz intuicję, aby uzyskać najlepszą liczbową reprezentację swoich ocen werbalnych. Wyprowadzone przez niego odwzorowanie może mieć charakter liniowy, np. jeżeli najniższym poziomem werbalnym jest „bardzo niski” (odpowiada mu wartość liczbowa 1), to kolejnym poziomom moga odpowiadać następujące wartości: „,niski” $=2$, „,́redni” $=3$, ,wysoki” $=4$, , ,bardzo wysoki” $=5$. Wiąże się to z tym, że w ocenie użytkownika poziom niski jest dwa razy wyższy od najniższego, średni trzy razy wyższy itd. Użytkownik może także odczuwać, że jego oceny lepiej odzwierciedli skala nieliniowa, przyjmując np. następującą skalę: „niski” $=2$, „średni” $=3$, „wysoki” $=6$, „bardzo wysoki” $=9$. W sposób oczywisty zero reprezentuje brak wpływu, co w grafie ilustruje się brakiem odpowiedniego łuku. Pewne składniki moga równocześnie mieć zerowe znaczenie (siłę), co zwykle wynika $\mathrm{z}$ ich roli w systemie. Na przykład, jeżeli metoda WINGS będzie miała służyć wielokryterialnemu wspomaganiu decyzji, to znaczenie (siła) elementu, który odgrywa rolę celu (kryterium), będzie odzwierciedlać jego wage - typowy parametr charakteryzujący cel w wielokryterialnych metodach wspomagania decyzji. Warianty decyzyjne nie maja, a nawet nie mogą mieć, przypisanych wag, stąd przypisuje się im zerowe wartości znaczenia. Mechanizm metody prowadzi do tego, że znaczenie wariantów pojawia się jako konsekwencja ich wpływów (bezpośrednich i pośrednich) na pozostałe elementy systemu - w szczególności na cele.

W przypadku kwestii negocjacyjnych, które ze swojej natury mają charakter ilościowy, można wprowadzić bezpośrednie odwzorowanie zbioru wartości liczbowych odpowiadających ofertom na wybraną skalę metody WINGS. Odwzorowanie to przyjmie postać, odpowiednio wyskalowanej, funkcji - liniowej lub nieliniowej. Taka sytuacja wystąpi w omawianym, w dalszej części artykułu, przykładzie.

Druga faza metody ma charakter techniczny. Jej głównym punktem jest obliczenie pełnych (końcowych) wpływów danego elementu na inny element w systemie. Polega on na obliczeniu wpływów wzdłuż wszystkich możliwych ścieżek o różnej długości, łączących wybrane elementy systemu: ten, którego wpływy oblicza się z tym, na który on wpływa. Następnie wpływy te są sumowane względem wszystkich składników. 
Taki sumaryczny wynik składnika stanowi podstawę oceny jego znaczenia i roli w systemie.

Faza obliczeniowa metody ma następujący przebieg (przyjmuje się, że system zbudowany przez użytkownika składa się z $n$ elementów):

1. Wszystkie wartości określone przez użytkownika wprowadza się do macierayy bezpośredniego znaczenia-wpływów $\mathbf{D}$. Elementy tej macierzy oznacza się jako $d_{i j}$, $i, j=1, \ldots, n$ :

- $\quad$ wartości reprezentujące znaczenie składników wprowadza się na główną przekątną: $d_{\mathrm{ii}}=$ znaczenie składnika $i$;

- $\quad$ wartości reprezentujące wpływy są wprowadzane w taki sposób, że $d_{i j}=$ wpływ składnika $i$ na składnik $j ; i, j=1, \ldots, n, i \neq j$;

2. Macierz $\mathbf{D}$ skaluje się zgodnie z następującą formułą:

$$
\mathbf{S}=\frac{1}{s} \mathbf{D}
$$

gdzie czynnik skalujący $s$ zdefiniowany jest jako suma elementów macierzy D:

$$
s=\sum_{i=1}^{n} \sum_{j=1}^{n} d_{i j},
$$

3. Oblicza się macierz całkowitego znaczenia-wpływów $\mathbf{T}$ zgodnie z wzorem:

$$
\mathbf{T}=\mathbf{S}+\mathbf{S}^{2}+\mathbf{S}^{3}+\ldots=\mathbf{S}(\mathbf{I}-\mathbf{S})^{-1}
$$

Dzięki skalowaniu nieskończony szereg występujący w powyższym równaniu jest zbieżny (szczegóły matematyczne wyjaśnione są w artykule: [Michnik, 2013]).

Związek pomiędzy macierzami a grafami skierowanymi pozwala na czytelną interpretację powyższych formuł. Wobec tego wyraz macierzy $\mathbf{S}^{k}(\mathrm{k}$-ta potęga macierzy $\mathbf{S})$ o wskaźnikach $i j$ jest iloczynem wpływów elementu o numerze $i$ na element $j$ wzdłuż ścieżki o długości k łuków (jeżeli takiej ścieżki nie ma, to dany wyraz macierzy $\mathbf{S}^{k}$ jest zerowy). Macierz $\mathbf{T}$, czyli suma wszystkich potęg macierzy $\mathbf{S}$, obejmuje wpływy po ścieżkach o dowolnej długości. Oczywiście, na wartość całkowitych wpływów składają się także niezerowe wartości znaczenia elementów należących do danej ścieżki. Z matematycznego punktu widzenia znaczenie (siła) elementu odpowiada „samosprzężeniu”, czyli łukowi, który zaczyna się i kończy w tym samym węźle. W efekcie, jeżeli w sieci występuje chociaż jedna niezerowa wartość znaczenia (siły), pojawią się w niej ścieżki o dowolnej, dużej długości. Stąd w sumie (3) wystąpią dowolnie duże potęgi macierzy S. Cecha ta odróżnia metodę WINGS od metod ilościowych opartych na mapach poznawczych. W metodach tych zwykle ścieżki mają skończone długości, co wynika z zalecenia unikania cykli (pętli) w sieciach reprezentujących mapy poznawcze.

Ostatnia faza metody WINGS to wykorzystanie informacji zawartej w macierzy T. Służą do tego wielkości zdefiniowane poniżej. 


\section{Całkowity wpływ}

Wielkość ta obejmuje wpływy wywierane przez składnik $i$ systemu na system (wszystkie składniki). Jest ona sumą elementów macierzy $\mathbf{T}$ należących do wiersza $i$ :

$$
I_{i}=\sum_{i=1}^{n} t_{i j} .
$$

\section{Całkowita podatność}

Jeżeli zsumuje się elementy należące do kolumny $i$ w macierzy $\mathbf{T}$, uzyska się wielkość obrazującą łączne wpływy wywierane przez składniki systemu na wybrany składnik $i$ :

$$
\mathrm{R}_{i}=\sum_{j=1}^{n} t_{i j} .
$$

\section{Całkowite zaangażowanie}

Suma wpływów wywieranych przez wybrany składnik i wpływów, którym podlega, czyli $I_{i}+R_{i}$, określa zaangażowanie składnika w system.

\section{Rola składnika}

Różnica pomiędzy wpływami wywieranymi przez składnik a wpływami, którym podlega, czyli $I_{i}-R_{i}$, określa rolę (pozycję) składnika w systemie. Wartość dodatnia oznacza przewagę wpływów wywieranych nad tymi, którym składnik podlega. Taki składnik można nazwać wpływającym; jego rola w systemie ma charakter przyczynowy. Wartość ujemna wskazuje na przewagę podlegania wpływom, czyli na charakter skutkowy.

W wyniku analizy zrobionej za pomocą metody WINGS, użytkownik uzyskuje sumaryczną charakterystykę składników w systemie wynikającą z ich wewnętrznego (początkowego) znaczenia oraz wpływu na pozostałe elementy systemu. Wartości liczbowe poszczególnych wielkości pozwalają na uszeregowanie składników. Pomocne w wyciagnięciu wniosków może być zilustrowanie położenia składników na wykresach, których osie stanowią, zdefiniowane powyżej, wielkości charakteryzujące składniki.

\section{Przykład zastosowania procedury WINGS w negocjacjach zakupu partii produktu}

Warto rozważyć problem negocjacyjny, w którym dwie strony negocjują kontrakt dotyczący zakupu pewnego dobra. Przyjmuje się, że w czasie wstępnej fazy strony uzgodniły zakres kwestii, które będa przedmiotem negocjacji. Obejmuje on (w nawiasach kwadratowych jest podany określony na wstępie zakres zmienności liczbowej charakterystyki dla danej kwestii): 
- cenę jednostkowa, [30, 45] (jednostki pieniężne);

- warunki płatności, [7, 30] (dni);

- termin dostawy, [14, 28] (dni);

- okres gwarancji, [6, 24] (miesiące);

- akceptowany limit braków, [0, 5] (procent);

- skalę kar umownych, [0, 10] (procent).

Istotne składniki systemu zostały już zdefiniowane, dlatego zgodnie z procedura metody WINGS, należy teraz przejść do określenia zależności pomiędzy nimi.

Do oceny werbalnej przyjmuje się, wymienioną wcześniej, skalę pięciopunktową: bardzo niski, niski, średni, wysoki, bardzo wysoki. Dla większego zróżnicowania ocen wprowadzono również oceny pośrednie: pomiędzy bardzo niski i niski, pomiędzy niski i średni itd. Liniowa skala liczbowa, odpowiadająca wybranej skali ocen, może składać się z liczb całkowitych od 1 do 9. Liczby nieparzyste: 1, 3, 5, 7, 9 będą odpowiadać głównym punktom skali, a liczby parzyste: 2, 4, 6, 8-ocenom pośrednim. Wynik oszacowania poziomu znaczenia (wag) kwestii negocjacyjnych oraz wpływów przeprowadzony przez strony ilustrują rysunki: 1. i 2 .

\section{Graf zależności dla strony kupującej}

RYSUNEK 1.

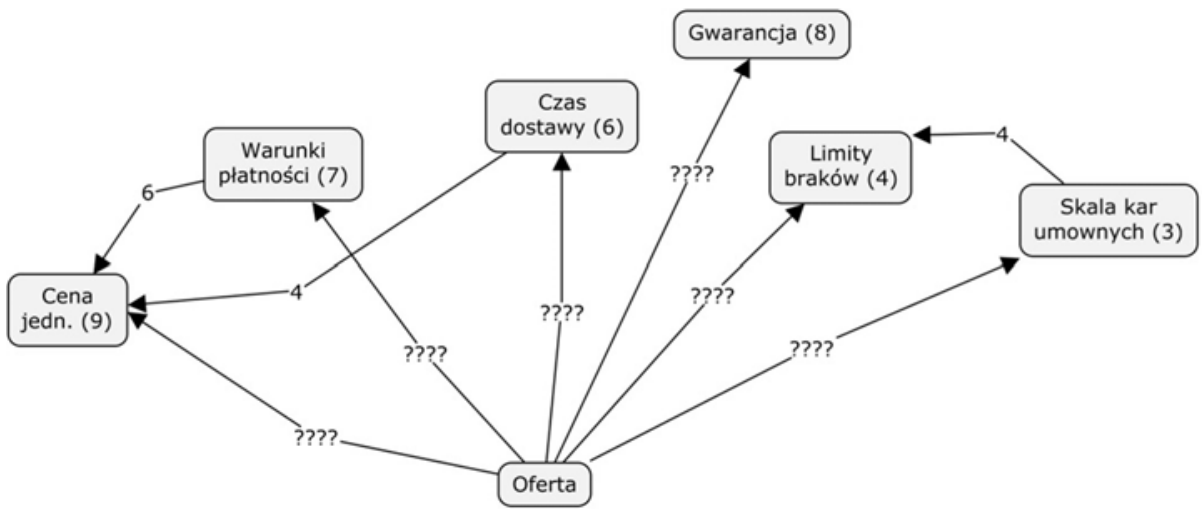

Źródło: opracowanie własne.

Ze względu na to, że wszystkie kwestie negocjacyjne są scharakteryzowane ilościowo, w ocenie wpływu oferty na kwestie negocjacyjne można pominąc ocenę werbalną i dokonać odwzorowania wartości źródłowych na wybraną skalę. Przyjęto odwzorowanie liniowe. Dla kwestii, która ma dla strony charakter korzyści, odwzorowanie to będzie miało postać:

$$
e_{j}=m \frac{z_{j}-\min \left(z_{j}\right)}{\max \left(z_{j}\right)-\min \left(z_{j}\right)},
$$


a dla kwestii, która ma charakter niekorzyści:

$$
e_{j}=m \frac{\max \left(z_{j}\right)-z_{j}}{\max \left(z_{j}\right)-\min \left(z_{j}\right)} .
$$

W powyższych równaniach $m$ oznacza maksymalną ocenę liczbową wybranej skali, $z-$-wartość $j$ opcji w ofercie, $e_{j}$ - wartość opcji w skali WINGS. W naszym przypadku $m=9$.

RYSUNEK 2.

\section{Graf zależności dla strony sprzedającej}

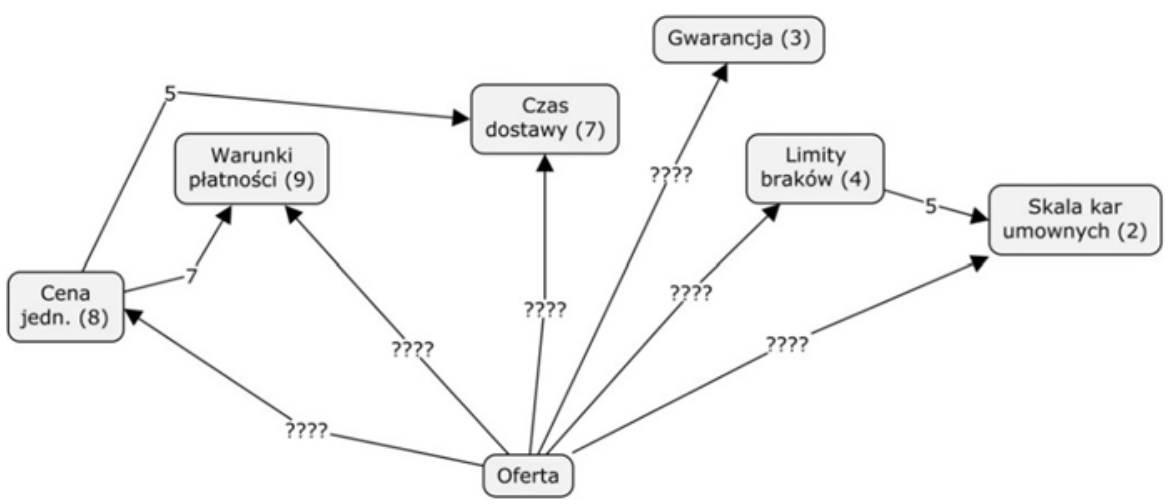

Źródło: opracowanie własne.

Jak widać, oceny ważności poszczególnych kwestii są różne dla kupującego i sprzedającego. W omawianym przykładzie sprzedający nieco niżej od kupującego określił wagę ceny, ale za to wyżej kwestię warunków płatności. Zależności pomiędzy rozpatrywanymi przez negocjującą stronę kwestiami wyrażają się w tym, że zmiana oceny jednej kwestii wpływa na ocenę innej. Tu również mogą one być rozmaite dla różnych negocjatorów. Na przykład dla kupującego krótszy (lepszy) czas dostawy wpływa pozytywnie na cenę, tzn. jego ocena dotycząca ceny jednostkowej jest wyższa, niż gdyby była rozpatrywana niezależnie. Podobnie dłuższy czas płatności zwiększa w oczach kupującego ocenę ceny jednostkowej w stosunku do jej wartości w przypadku niezależności ocen. Dla sprzedającego wyższa cena jednostkowa jest lepsza. Jej większa wartość podwyższa ocenę czasu dostawy oraz warunków płatności w odniesieniu do poziomu, kiedy te kwestie byłyby niezależne. Analogicznie interpretuje się pozostałe zależności określone przez obie strony negocjacji.

\section{Przykładowy proces negocjacji}

Oferty składane przez strony w kolejnych rundach negocjacji oznaczono kolejnymi liczbami naturalnymi, przy czym liczba nieparzysta oznacza ofertę kupującego, a liczba parzysta - ofertę sprzedawcy. Każda oferta będzie zawierać proponowane wartości poszczególnych kwestii, w kolejności podanej uprzednio, a więc cena jednostkowa, 
warunki płatności, termin dostawy, okres gwarancji, akceptowany limit braków, skala kar umownych. Pierwszy ofertę składa kupujący. Początkowe oferty kupującego i sprzedającego zawierają najkorzystniejsze poziomy dla każdej ze stron, czyli oferta $1=(30$, $30,14,24,0,10)$, oferta $2=(45,7,28,6,5,0)$. Następnie w kolejnych rundach strony przedstawiaja swoje dalsze propozycje. Pełny zestaw ofert prezentuje tabela 1 . Wartości wpływów danej oferty na kwestie negocjacyjne, obliczone za pomoca wzorów: (6) i (7), są wprowadzane z kolei do macierzy $\mathbf{S}$, w której są również zawarte, ustalone wcześniej, znaczenia kwestii i wartości niezerowych zależności między nimi. Zagregowaną ocenę liczbową oferty wyraża całkowity wpływ. Zestawienie zagregowanych ocen kolejnych ofert, obliczone dla kupującego i sprzedawcy, jest także przedstawione w tabeli 1. W dodatku pokazana jest zawartość macierzy D, $\mathbf{S}$ oraz $\mathbf{T}$ w przypadku obliczenia przez kupującego zagregowanej oceny jego pierwszej oferty. Na marginesie warto zauważyć, że oferty charakteryzują się brakiem łuków wchodzących, co powoduje, że ich podatności są zerowe, a tym samym ich całkowite zaangażowanie jest równe całkowitemu wpływowi.

W każdym modelu oceny ofert pojawia się problem, gdy jedna ze stron (lub obie) wykroczy poza wcześniej uzgodniony przedział. Oznacza to wprowadzenie do oferty wartości lepszej lub gorszej od spodziewanej, czyli zmianę zdefiniowanej wcześniej przestrzeni negocjacyjnej. Taką zmianę należy uwzględnić w ocenie ofert, dokonując odpowiednich przeliczeń. Zwykle jest to bardziej kłopotliwe w przypadku modeli, które posługują się stałymi punktami odniesienia [Roszkowska, Wachowicz, 2015].

TABELA 1.

\section{Zestawienie ofert stron $\mathrm{i}$ ich zagregowanych ocen w przykładowym} procesie negocjacji

\begin{tabular}{|c|c|c|c|c|c|c|c|c|}
\hline Kwestia & $\mathbf{1}$ & $\mathbf{2}$ & $\mathbf{3}$ & $\mathbf{4}$ & $\mathbf{5}$ & $\mathbf{6}$ & $\mathbf{7}$ & $\mathbf{8}$ \\
\hline Cena jednostkowa & 30 & 35 & 36 & 36 & 45 & 40 & 40 & 36 \\
Warunki płatności & 30 & 25 & 20 & 15 & 7 & 14 & 16 & 12 \\
Termin dostawy & 14 & 14 & 16 & 18 & 28 & 21 & 18 & $\mathbf{1 2}$ \\
Okres gwarancji & 24 & 24 & 18 & 18 & 6 & 12 & 12 & 18 \\
Akceptowany limit braków & 0 & 2 & 3 & 2 & 5 & 3 & 3 & 2 \\
Skala kar umownych & 10 & 8 & 5 & 5 & 0 & 3 & 3 & 5 \\
\hline Zagregowane oceny przed zmianą przestrzeni negocjacyjnej \\
\hline Ocena kupującego & 0,514 & 0 & 0,461 & 0,276 & 0,388 & 0,346 & 0,376 & 0,386 \\
Ocena sprzedawcy & 0 & 0,518 & 0,177 & 0,406 & 0,301 & 0,348 & 0,315 & 0,302 \\
\hline Zagregowane oceny po zmianie przestrzeni negocjacyinej \\
\hline Ocena kupującego \\
Ocena sprzedawcy
\end{tabular}

Numery nieparzyste - oferty kupującego, numery parzyste - oferty sprzedawcy.

Źródło: opracowanie własne. 
Wykorzystując oryginalną wersję metody WINGS, prowadzący negocjacje musi dokonać powtómej oceny wszystkich ofert w zakresie tej opcji, w której druga strona wykroczyła poza uzgodniony zakres. W tym przykładzie oferty są oceniane według formuł: (6) i (7). Zmiana wymaga dokonania ponownych obliczeń ze zmienioną wartością funkcji 'max' lub 'min', zależnie od poziomu oferty. W przykładowym procesie negocjacji sprzedający w ostatniej rundzie (oferta 8) skrócił proponowany termin dostawy do 12 dni, co wykracza poza uzgodnione minimum 14 dni (w tabeli 1 . liczba jest wyróżniona tłustą czcionka). Obie strony muszą zrewidować dotychczasowe oceny poprzez zmianę we wzorach: (6) i (7) wartości 'min' dla terminu dostawy z 14 na 12. W efekcie kupujący obniży oceny wszystkich (swoich i sprzedającego) ofert złożonych w poprzednich rundach. Natomiast oceny poprzednich ofert zostana podwyższone przez sprzedającego. Na przykład początkowa oferta kupującego miała u sprzedawcy ocenę 0 , zaś po modyfikacji ocena ta zwiększyła się do 0,021 (tabela 1.). Graficzną ilustrację kształtowania się ocen w trakcie omawianego procesu negocjacji zawiera rysunek 3 .

RYSUNEK 3.

Oceny kupującego i sprzedawcy ofert własnych i drugiej strony w przykładowym przebiegu negocjacji (po zmianie przestrzeni negocjacyjnej)

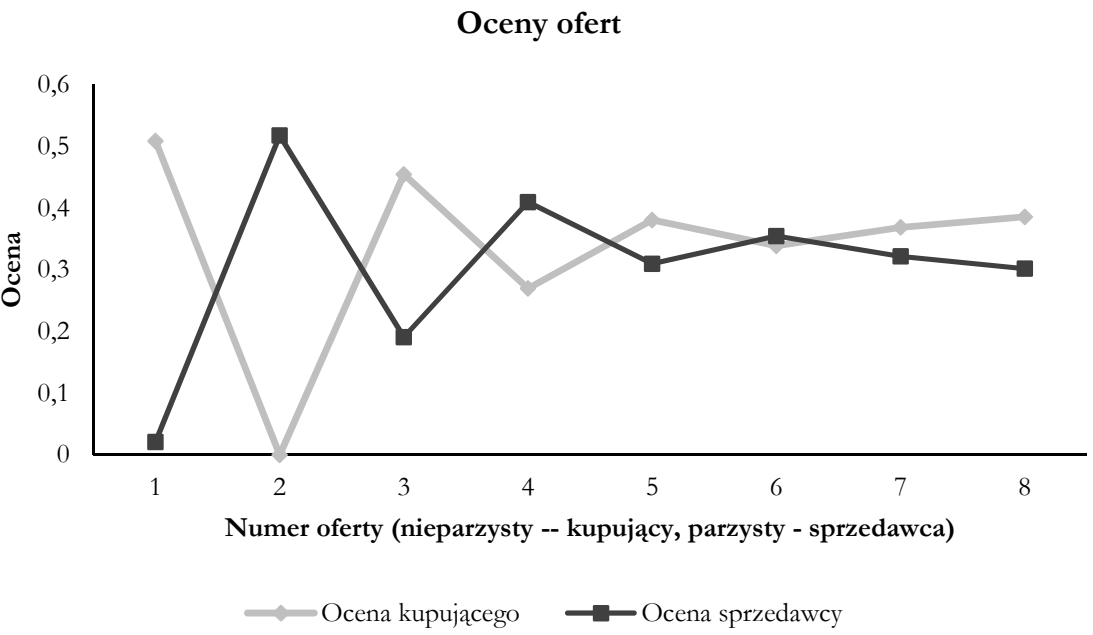

Numery ofert (nieparzyste - kupujący, parzysty - sprzedawca).

Źródło: opracowanie własne na podstawie danych z tabeli 1.

\section{Przykład zastosowania procedury WINGS w przygotowaniu do negocjacji zakupu systemu informatycznego}

W obecnych czasach trudno byłoby prowadzić szeroką działalność gospodarczą bez dysponowania odpowiednim systemem informatycznym. W średnich i dużych firmach 
stosuje się systemy klasy ERP (Enterprise Resource Planning). Zakup takiego systemu wymaga dużych nakładów rzeczowych i wysiłku organizacyjnego. Wdrożenie systemu jest projektem o dużym ryzyku. Stąd wynika strategiczne znaczenie decyzji związane z wyborem odpowiedniego dostawcy oraz wariantu systemu.

Istnieje bardzo bogata literatura, która odnosi się do kwestii wyboru systemu ERP przez podmiot gospodarczy. Modele wspomagające taki wybór są oparte na odpowiednio dobranych metodach wielokryterialnych. Jako przykłady mogą służyć wybrane artykuły [Kilic i in. 2014; Wei i in. 2005; Wei, Wang, 2004]. Niektórzy autorzy, uznając za ważne zależności między kryteriami, oparli swoje procedury na metodzie ANP [de Medeiros (Jr.) $i$ in. 2014; Gürbüz i in. 2012; Wieszała i in. 2011], która to metoda należy do najpopularniejszych sposobów obejścia klasycznego założenia o niezależności kryteriów [Saaty, 2005].

Celem ilustracji zastosowania procedury WINGS w przygotowaniu do negocjacji z dostawcą przyjęto uproszczony model uwzględniający tylko wybrane kwestie ważne dla oceny systemu ERP. Zostały one podzielone na trzy grupy [Gürbüz i in. 2012; Wieszała i in. 2011]. Pierwsza grupa odnosi się do potrzeb nabywcy, a więc uwzględnia jego cechy charakterystyczne. Do grupy tej zalicza się dopasowanie do strategii firmy - czyli do obecnej sytuacji i przyszłych długoterminowych planów rozwojowych (dopasowanie strategiczne). Drugą kwestią jest wpływ systemu na usprawnienie procesów w firmie. Do ważnych kwestii należy również dopasowanie systemu do struktury organizacyjnej firmy. W przypadku, kiedy firma jest częścią większej organizacji gospodarczej, w grę może także wchodzić dopasowanie do struktury (i ewentualnie systemów) w jednostkach powiązanych (nadrzędnych lub zależnych).

Druga grupa dotyczy kwestii powiązanych z charakterystyką systemu ERP (funkcjonalność produktu). Obejmuje ona takie cechy, jak elastyczność systemu i łatwość w użyciu. Ważną cechą jest poziom bezpieczeństwa danych. Na wyższą ocenę oddziałuje równocześnie poziom integracji poszczególnych modułów składających się na system. W tej grupie znajdują się jednocześnie trzy składniki kosztów finansowych, tj.: koszty licencji, wdrożenia i eksploatacji.

Ostatnia grupa uwzględnia te elementy charakterystyki dostawcy, które mają wpływ na decyzję o podjęciu z nim współpracy. Należy do nich pozycja rynkowa, która przede wszystkim zawiera: udział w rynku, dotychczasowe kontrakty i opinię innych kontrahentów. O zdolności dostawcy do sprawnego wdrożenia systemu świadczy równocześnie jego sytuacja finansowa i kompetencje organizacyjne. Istotnym aspektem oceny systemu jest obsługa serwisowa i warunki dostępu do aktualizacji. Tu umieszczony jest również czas wdrożenia.

Jak już wcześniej wspomniano, przykład ma ilustrować sposób działania i nie pretenduje do kompletnego i wystarczająco szczegółowego modelu. W rzeczywistej sytuacji moga pojawić się jeszcze inne kwestie, kluczowe dla firmy kupującej system. Jednocześnie można spodziewać się, że będzie potrzebna bardziej szczegółowa analiza poszczególnych kwestii. Na przykład kwestia usprawniania procesów może zostać rozłożona na cząstkowe kwestie odnoszące się do poszczególnych procesów, takich jak: produkcja, logistyka, rachunkowość i kontrola, zarządzanie zasobami ludzkimi itp. Kwestia bezpieczeństwa może być podzielona na bezpieczeństwo przechowywania 
i bezpieczeństwo przesyłania danych. $Z$ dopasowania strategicznego można wydzielić kwestie związane z możliwościami systemu wspierania decyzji strategicznych. Jednakże nadmiar szczegółów nie pomógłby w realizacji głównego celu, jakim jest pokazanie sposobu wykorzystania procedury WINGS.

Struktura sieci zależności dla wyboru systemu ERP jest przedstawiona na rysunku 4. Obejmuje ona, wymienione powyżej, kwestie i ich powiązania. Zaznaczone sa przykładowe wartości znaczenia poszczególnych kwestii oraz siły wpływu (aby rysunek był przejrzysty, nie umieszczono na nim oferty i jej oceny względem poszczególnych kwestii). Do ocen znaczenia i siły wpływu użyto jednolitej skali liczb całkowitych od 1 do 9. W odróżnieniu od poprzedniego przypadku, znaczna część kwestii ma charakter jakościowy i ocena w większym stopniu odzwierciedla preferencje podmiotu oceniającego. Dlatego, zamiast formuł: (6) i (7), należy tutaj zastosować bezpośrednią ocenę w wybranej skali. Zaletą takiego rozwiązania jest lepsze odwzorowanie preferencji. $\mathrm{Na}$ przykład duże znaczenie w ocenie oferty mają koszty systemu. Jednak gdy dla dwóch rozmaitych ofert różnica w koszcie jest mała, nie jest uzasadnione przypisywanie im różnych ocen. Kwestia ceny przestaje mieć znaczenie przy porównaniu ofert, co można uzyskać przyjmując tę samą wartość oceny kwestii kosztów dla ofert, które różnią się kosztami w sposób nieznaczący dla oceniającego. Należy oczywiście pamiętać, że koszty (jak i czas wdrożenia) mają charakter niekorzyści i większej ich wartości będzie odpowiadać niższa ocena. Trzeba również pamiętać o pozytywnym charakterze powiązań w sieci WINGS. Tak więc, wpływ pozycji rynkowej i bezpieczeństwa na kwestię kosztów oznacza, że uzyskują one względnie wyższą ocenę, kiedy firma ma lepszą pozycję, a system jest oceniany jako bardziej bezpieczny.

W odniesieniu do struktury przedstawionej na rysunku 4. można obliczyć wyjściowe wielkości metody WINGS dla każdego elementu należącego do systemu. Uzyska się w ten sposób całkowite zaangażowanie każdego elementu, które określa przypisane mu znaczenie zmodyfikowane wzajemnymi relacjami. Taka analiza jest przydatna w fazie przygotowania do negocjacji. W tym przypadku całkowite zaangażowanie trzech głównych kwestii, które reprezentuje efektywne wagi przypisane kryteriom w modelu, przedstawia się następująco (przeskalowane tak, że ich suma wynosi 1): potrzeby nabywcy $-0,28$, funkcjonalność produktu $-0,43$, charakterystyka dostawcy $-0,29$. Ich stosunki liczbowe odbiegaja od stosunków znaczenia tych kwestii, przypisanych im na początku procedury. Jest to świetna ilustracja wagi, jaką mają: liczba i znaczenie poszczególnych składników systemu oraz przede wszystkim relacji pomiędzy nimi.

W praktyce dalsze postępowanie mogłoby wyglądać następująco: dokonuje się wstępnej selekcji dostawców, których systemy spełniają pewne minimalne wymagania (ten etap odpowiada określeniu zbioru rozwiązań dopuszczalnych w postępowaniu optymalizacyjnym). Jeżeli wyselekcjonowany zbiór jest odpowiednio mały (w praktyce 2-3 dostawców), można przejść do negocjacji. Jeśli jednak zbiór ten jest zbyt liczny, można przeprowadzić dalszą selekcję za pomoca przygotowanego modelu. W trakcie negocjacji z wybranymi dostawcami, podobnie jak to pokazano w poprzednim przykładzie, dokonuje się oceny każdej oferty, przypisując jej wartości poziomu realizacji wszystkich kwestii. Następnie za pomoca metody WINGS oblicza się całkowity wpływ danej oferty, który stanowi zagregowaną jej ocenę. 


\section{Struktura sieci WINGS dla problemu wyboru systemu ERP}

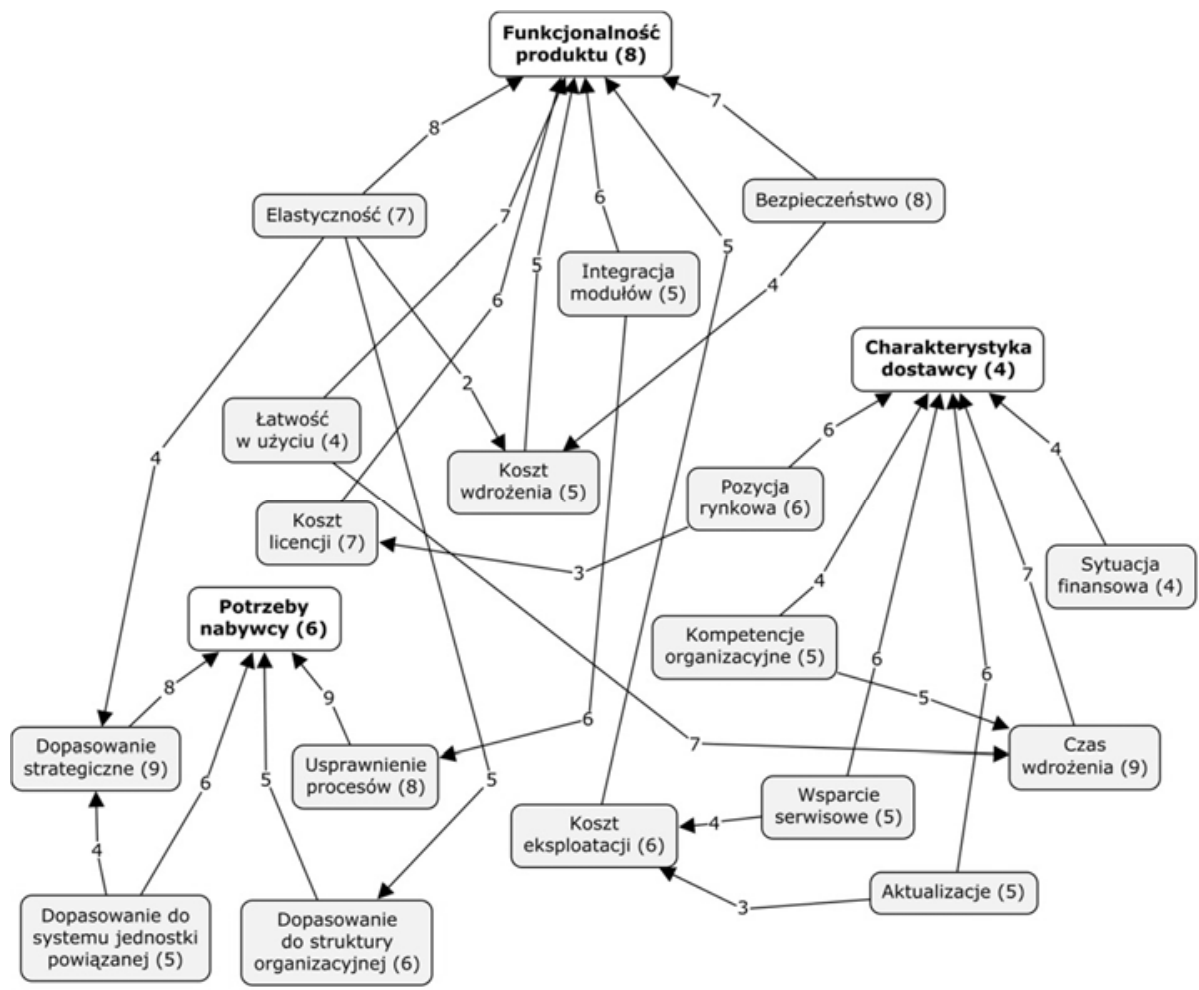

Źródło: opracowanie własne.

\section{Podsumowanie}

Metoda WINGS może być przydatnym narzędziem we wspieraniu procesu negocjacji. W fazie prenegocjacyjnej pomaga zespołowi negocjacyjnemu w określeniu istotnych kwestii, ich względnej ważności oraz zależności między nimi. W bardziej skomplikowanych przypadkach może zostać wsparta rozbudowanymi procedurami strukturyzacji problemu, takimi jak SODA lub SSM. W obu fazach - prenegocjacyjnej i właściwych negocjacji - użytkownik musi podać stosunkowo niewielką ilość informacji charakteryzujących jego preferencje i punkt widzenia na strukturę problemu. To daje jej przewage nad metodą ANP, w której liczba porównań parami szybko rośnie z liczbą elementów, czyniąc ją niepraktyczną w skomplikowanych przypadkach. Drugi aspekt przewagi WINGS nad ANP jest związany z mało intuicyjnym dla użytkownika sposobem kalibracji pierwotnej supermacierzy w metodzie ANP [Saaty, 2005].

W wyniku zastosowania metody WINGS użytkownik uzyskuje jasny obraz sytuacji, ponieważ każda oferta - zarówno jego, jak i strony przeciwnej - zostaje oceniona za 
pomoca zagregowanej oceny liczbowej. W pierwszym z przykładów pokazano, że metoda łatwo radzi sobie z niestabilną przestrzenią negocjacyjna. Jednocześnie jej wysoki poziom elastyczności pozwala na dostosowanie do różnych specyficznych potrzeb. W szczególności jej przydatność zyskuje na znaczeniu w sytuacjach, kiedy mamy do czynienia z bardziej złożonymi przypadkami, obejmującymi hierarchiczną strukturę kwestii negocjacyjnych i kiedy wzrasta rola wzajemnych zależności. Należy zwrócić uwagę, że pod względem technicznym nie stwarza żadnych problemów, podczas gdy podobna do niej metoda ANP wymaga skomplikowanych obliczeń i niejednokrotnie nie prowadzi do jednoznacznych wyników [Saaty, 2005]. Prostota techniczna metody WINGS ułatwia również jej implementację, zwłaszcza do obliczeń można wykorzystać dowolny arkusz kalkulacyjny lub program do obliczeń matematycznych. Wynika to z tego, że w WINGS obliczenia nie wykraczaja poza standardowe operacje na macierzach kwadratowych.

\section{Literatura}

Brzostowski J., Roszkowska E., Wachowicz T., 2012a, Using Multiple Criteria DecisionMaking Methods in Negotiation Support, „Optimum. Studia Ekonomiczne”, nr 3(29).

Brzostowski J., Roszkowska E., Wachowicz T., 2012b, Using an Analytic Hierarchy Process to develop a scoring system for a set of continuous feasible alternatives in negotiation, „Operations Research and Decisions", no. 4.

Górecka D., Roszkowska E, Wachowicz T., 2014, MARS - a bybrid of ZAPROS and $M A C B E T H$ for verbal evaluation of the negotiation template, Group Decision and Negotiation 2014 : GDN 2014 : Proceedings of the Joint International Conference of the INFORMS GDN Section and the EURO Working Group on DSS, P. Zaraté, G. Camilleri, D. Kamissoko, F. Amblard (red.), Toulouse University, France:

Górecka D., Roszkowska E., Wachowicz T., 2016, The MARS Approach in the Verbal and Holistic Evaluation of the Negotiation Template, "Group Decision and Negotiation", DOI: 10.1007/s10726-016-9475-92016.

Gürbüz T., Alptekin S. E., Iş1klar Alptekin G., 2012, A hybrid MCDM methodology for ERP selection problem with interacting criteria, „Decision Support Systems”, 54, doi:10.1016/j.dss.2012.05.006.

Kersten G. E., Noronha S. J., 1999, WWW-based negotiation support: design, implementation, and use, „Decision Support Systems” 25, doi:10.1016/S0167-9236(99)00012-3.

Kilic H.S., Zaim S., Delen D., 2014, Development of a bybrid methodology for ERP system selection: The case of Turkish Airlines, „Decision Support Systems” 66, doi: 10.1016/ j.dss.2014.06.011.

de Medeiros (Jr.) A., Perez G., Lex S., 2014, Using Analytic Network for Selection of Enterprise Resource Planning Systems (ERP) Aligned To Business Strategy, ,Journal of Information Systems and Technology Management", no. 11.

Michnik J., 2013, Weighted Influence Non-linear Gauge System (WINGS) - An analysis method for the systems of interrelated components, „European Journal of Operational Research", 228. 
Mustajoki J., Hämäläinen R. P., 1999, Web-HIPRE - Global decision support by value tree and AHP analysis, Presented at the INFOR.

Systems Modelling: Theory and Practice, 2004, M. Pidd (ed.), John Wiley \& Sons.

Roszkowska E., Wachowicz T., 2015, Application of fuzzy TOPSIS to scoring the negotiation offers in ill-structured negotiation problems, „European Journal of Operational Research” 242, doi:10.1016/j.ejor.2014.10.050.

Roszkowska E., Wachowicz T., 2016, Negocjacje. Analiza i wspomaganie decyzji, Wolter Kluwer, Warszawa.

Saaty T. L., 2005, Theory and Applications of the Analytic Network Process. Decision Making with Benefits, Opportunities, Costs and Risks, RWS Publications, Pittsburgh.

Salo A., Hämäläinen R. P., 2010, Multicriteria Decision Analysis in Group Decision Processes, [in:] Handbook of Group Decision and Negotiation, D.M. Kilgour, C. Eden (eds.), Advances in Group Decision and Negotiation, Springer Netherlands.

Wachowicz T., 2013, Metody wielokryterialne we wspomaganiu prenegocjacyjnego praygotowania negocjatorów, Wydawnictwo Uniwersytetu Ekonomicznego w Katowicach, Katowice.

Wei C.-C., Chien C.-F., Wang M.-J. J., 2005, An AHP-based approach to ERP system selection, „International Journal of Production Economics” 96, doi:10.1016/j.ijpe.2004.03.004.

Wei C.-C., Wang M.-J. J., 2004, A comprehensive framework for selecting an ERP system, „International Journal of Project Management” 22, doi:10.1016/S0263-7863(02)00064-9.

Wieszała P., Trzaskalik T., Targiel K., 2011, Analytic Network Process in ERP Selection, [in:] Multicriteria Decision Making'10-11, University of Economics in Katowice, Katowice.

\section{DODATEK}

TABELA D1.

Zawartość macierzy D dla obliczenia za pomocą metody WINGS zagregowanej oceny kupującego dla jego pierwszej oferty

\begin{tabular}{|l|c|c|c|c|c|c|c|c|}
\hline \multicolumn{1}{|c|}{ Pozycja } & $\mathbf{N r}$ & $\mathbf{1}$ & $\mathbf{2}$ & $\mathbf{3}$ & $\mathbf{4}$ & $\mathbf{5}$ & $\mathbf{6}$ & $\mathbf{7}$ \\
\hline Cena jednostkowa & 1 & 9 & 0 & 0 & 0 & 0 & 0 & 0 \\
\hline Warunki płatności & 2 & 6 & 7 & 0 & 0 & 0 & 0 & 0 \\
\hline Termin dostawy & 3 & 4 & 0 & 6 & 0 & 0 & 0 & 0 \\
\hline Okres gwarancji & 4 & 0 & 0 & 0 & 8 & 0 & 0 & 0 \\
\hline Akceptowany limit braków & 5 & 0 & 0 & 0 & 0 & 4 & 0 & 0 \\
\hline Skala kar umownych & 6 & 0 & 0 & 0 & 0 & 4 & 3 & 0 \\
\hline Oferta & 7 & 9 & 9 & 9 & 9 & 9 & 9 & 0 \\
\hline
\end{tabular}

Źródło: opracowanie własne. 
TABELA D2.

Zawartość macierzy S dla danych z tabeli D1

\begin{tabular}{|l|l|l|l|l|l|l|l|l|}
\hline \multicolumn{1}{|c|}{ Pozycja } & $\mathbf{N r}$ & \multicolumn{1}{c|}{$\mathbf{1}$} & \multicolumn{1}{|c|}{$\mathbf{2}$} & \multicolumn{1}{|c|}{$\mathbf{3}$} & \multicolumn{1}{|c|}{$\mathbf{5}$} & \multicolumn{1}{|c|}{$\mathbf{6}$} & \multicolumn{1}{c|}{} \\
\hline Cena jednostkowa & 1. & 0,0857 & 0 & 0 & 0 & 0 & 0 & 0 \\
\hline Warunki płatności & 2. & 0,0571 & 0,0667 & 0 & 0 & 0 & 0 & 0 \\
\hline Termin dostawy & 3. & 0,0381 & 0 & 0,0571 & 0 & 0 & 0 & 0 \\
\hline Okres gwarancji & 4. & 0 & 0 & 0 & 0,0762 & 0 & 0 & 0 \\
\hline Akceptowany limit braków & 5. & 0 & 0 & 0 & 0 & 0,0381 & 0 & 0 \\
\hline Skala kar umownych & 6. & 0 & 0 & 0 & 0 & 0,0381 & 0,0286 & 0 \\
\hline Oferta & 7. & 0,0857 & 0,0857 & 0,0857 & 0,0857 & 0,0857 & 0,0857 & 0 \\
\hline
\end{tabular}

Źródło: opracowanie własne.

TABELA D3.

\section{Zawartość macierzy $T$ dla danych z tabel: D1 i D2}

\begin{tabular}{|l|l|l|l|l|l|l|l|l|}
\hline \multicolumn{1}{|c|}{ Pozycja } & $\mathbf{N r}$ & \multicolumn{1}{|c|}{$\mathbf{1}$} & \multicolumn{1}{|c|}{$\mathbf{2}$} & \multicolumn{1}{|c|}{$\mathbf{3}$} & \multicolumn{1}{|c|}{$\mathbf{4}$} & $\mathbf{5}$ & $\mathbf{6}$ & $\mathbf{7}$ \\
\hline Cena jednostkowa & 1. & 0,0938 & 0 & 0 & 0 & 0 & 0 & 0 \\
\hline Warunki płatności & 2. & 0,0670 & 0,0714 & 0 & 0 & 0 & 0 & 0 \\
\hline Termin dostawy & 3. & 0,0442 & 0 & 0,0606 & 0 & 0 & 0 & 0 \\
\hline Okres gwarancji & 4. & 0 & 0 & 0 & 0,0825 & 0 & 0 & 0 \\
\hline Akceptowany limit braków & 5. & 0 & 0 & 0 & 0 & 0,0396 & 0 & 0 \\
\hline Skala kar umownych & 6. & 0 & 0 & 0 & 0 & 0,0408 & 0,0294 & 0 \\
\hline Oferta & 7. & 0,1032 & 0,0918 & 0,0909 & 0,0928 & 0,0926 & 0,0882 & 0 \\
\hline
\end{tabular}

Źródło: opracowanie własne. 